Selcuk Journal of Agriculture and Food Sciences

http://sjafs.selcuk.edu.tr/sjafs/index

Research Article
SJAFS

(2020) 34 (2), 162-168

e-ISSN: 2458-8377

DOI:10.15316/SJAFS.2020.211

\title{
The Effects of Malch Applications on the Seedling Quality of 110R and Fercal Grape Rootstocks*
}

\author{
(iD Zeki KARA ${ }^{1, *}$, (D)Mohammed Salah Mohammednoorı FAKHAR ${ }^{2}$ \\ ${ }^{1}$ Selçuk University, Graduate School of Natural and Applied Sciences, Department of Horticulture, Konya, Turkey \\ ${ }^{2}$ Selçuk University, Faculty of Agriculture, Department of Horticulture, Konya, Turkey
}

\begin{tabular}{l}
\hline ARTICLE INFO \\
\hline Article history: \\
Received date: 19.06 .2020 \\
Accepted date: 30.06 .2020 \\
\hline Edited by: \\
Ali SABIR; Selçuk University, Turkey \\
Reviewed by: \\
Hatice BİLİ EKBİÇ; Ordu University, \\
Turkey \\
Aydın UZUN; Erciyes University, \\
Turkey
\end{tabular}

\section{Keywords:}

Grapevine rootstock,

Propagation,

Biodegradable mulch,

Organic mulch,

Plastic mulch

\begin{abstract}
Viticulture, in Turkey as well as all over the world is one of the most important agricultural activities as socio-economic issues. Significant quantities of highquality grapevine seedlings are needed to maintain and improve the current state of viticulture at national and global levels. Soil cultivation, irrigation and plant protection activities in the sapling production process not only increase the production cost, but also affect the yield and quality of the seedlings. In this study, mulch applications (Black plastic BP, Black plastic jute PJ, Biodegradable plastic BD, Wheat stalk OM and Control) of 110R and Fercal grape rootstocks obtained from the Sub-Union of Sapling Producers, from standard graftable quality virus free cuttings, in open area conditions was done. Effects of applications on seedling yield and quality (soil temperature $\left({ }^{\circ} \mathrm{C}\right)$, leaf temperature $\left({ }^{\circ} \mathrm{C}\right)$, stomatal conductivity $\left(\mathrm{mmol} \mathrm{m}^{-2} \mathrm{~s}^{-1}\right)$, leaf chlorophyll content (spad value), leaf area $(\mathrm{cm} 2)$, leaf number (pieces), leaf weight $(\mathrm{g})$, shoot length $(\mathrm{cm})$, shoot diameter $(\mathrm{mm})$, pruning residue weight $(\mathrm{g})$, shoot development level (0-4 scale), root numbers (pieces) and diameter $(\mathrm{mm})$, root fresh and dry weight $(\mathrm{g})$, root growth level (0-4 scale) and seedling efficiency $(\%)$ were examined. While mulch applications in general provided improvement in all parameters examined, the efficiency varied according to grapevine rootstocks and examined properties. In terms of seedling efficiency, BP application in Fercal rootstock and BD application in 110R rootstock were most effective. According to the data obtained from this study, the positive effects of BP and $\mathrm{BB}, \mathrm{PJ}$ and $\mathrm{OM}$ mulch applications were determined in the production of grape rootstock seedlings in open areas and especially in areas where the relative humidity was very low.
\end{abstract}

\section{Introduction}

Viticulture, in Turkey as well as all over the world is one of the most important agricultural activities as socio-economic issues. Turkey is 416907 ha of vineyards and grape production by 4.2 million tons, the world's 5th largest grape producer countries (Faostat 2020). Since the phyloxerae (Daktulospharia vitifoliae Fitch) moved from America to Europe at the end of the 19th century, seedling production, seedling yield and quality of grapevine rootstocks is one of the primary issues in the viticulture industry.

Traditional agricultural practices can affect the efficiency and durability of soil and environmental ecosystems, leading to soil degradation. Some common practices in traditional viticulture, such as the continu-

\footnotetext{
*Corresponding author email: zkara@selcuk.edu.tr

* This manuscript has been produced from the master thesis Mohammed Salah Mohammednoor1 Fakhar supported by Selcuk University Scientific Research Projects Board (SU BAP 20201020).
}

ous use of herbicides, may lead to increased soil quality and overall sustainability losses of the grape production system (Ingels 1992). In order to use water resources more efficiently, water saving methods have become mandatory (Kanber et al. 1991).

Mulching is a protective layer consisting of organic or inorganic materials applied on the soil to create a suitable environment for the soil surface, plant growth, development and efficient production around the plant (Bakshi et al. 2015). Viticulture experts want to protect a healthy and productive soil. Depending on the situation, mulch may be an appropriate option (Ross 2010).

Mulches affects soil temperature, moisture level, nutrition level, microorganism activity (Ross 2010; Mundy and Agnew 2002), suppresses weeds, and provides advantages by increasing seedling yield and quality in nurseries (Nauleau 1997; Wheeler et al. 2005; Nazrala 2008; Bakshi et al. 2015; Watson 2006; Chan et al. 2010; Arslan and Uygur 2014; Cowan 2013; Król-Dyrek and Siwek 2015; Zengin 2019; Dağ 2017; 
Küçükyumuk 2009; Zenginoğlu 2015; Zhang et al. 2014; Ferrara et al. 2012; Hostetler et al. 2007).

In this study, the effects of OM, BD, BP and PJ mulch applications used to improve seedling yield and quality in sapling production parcels created by direct planting of Fercal and 110R grape rootstocks for the production of rooted grapevine seedlings in open area conditions were examined.

\section{Material ve Metot}

OM (Wheat stalk): The wheat stalk in the bale form was laid in rows in the sapling production plot just before planting $80 \mathrm{~mm}$ wide and $10 \mathrm{~cm}$ thick vine rootstock cuttings.

$B P$ and $P J$ as inorganic malches were produced by Filesan İskenderun TR company for use as agricultural mulch, and they were laid at the $80 \mathrm{~cm}$ width of the sapling production parcel rows, $80 \mathrm{~cm}$ wide, just before planting of the rootstocks.

Biodegradable mulch (BD): The product, which was produced and introduced to the market for agricultural use through the Ankara Agricultural Market TR company, was laid just before planting $80 \mathrm{~cm}$ wide vine rootstock cuttings in the rows of seedlings production plots.

Control: It was a sapling production plot created directly under the influence of environmental extracts without applying any mulch.

Fercal [(Vitis vinifera L. $\times$ Vitis berlanderi L. $) \times$ $333 \mathrm{EM}$ ] and 110R (Berlandieri Resseguier No: $2 \times$ Rupestris Martin) were used as roorstock cuttings. Both of them are supplied as standard rootstock cuttings (TS 3981, TS 3912) from the Sapling Produrers Sub-Association. Trial 3 repetitive random blocks were established according to the trial pattern and the number of cuttings in the parcel was 30 .

Following the soil preparation, which was initiated in autumn and repeated in early spring, cutting were planted for the trial in early April as $15 \mathrm{~cm} \mathrm{x} 80 \mathrm{~cm}$ between cuttings, routine cultural practices was carried out in the summer period, records were kept and postharvest measurements were carried out by harvesting rooted saplings in autumn (in November).

The trial plots soil temperatures $\left({ }^{\circ} \mathrm{C}\right)$, leaf temperature $\left({ }^{\circ} \mathrm{C}\right.$, by SC-I Leaf Porometer), stomatal conductivity (mmol m $\mathrm{m}^{-2} \mathrm{~s}^{-1}$, by SC-I Leaf Porometer), leaf chlorophyll content [(spad value by Minolta Spad Meter 520,(Kara et al. 2017)], leaf area $\left(\mathrm{cm}^{2}\right)$, leaf number (pieces), leaf weight $(\mathrm{g})$, shoot length $(\mathrm{cm})$, shoot diameter $(\mathrm{mm})$, pruning residue weight $(\mathrm{g})$, shoot development level (0-4 scale), number of roots (pieces) and root diameter $(\mathrm{mm})$, root fresh and dry weight $(\mathrm{g})$, root growth level (0-4 scale) and seedling efficiency (first and second grade \%) were examined.

Statistical analyses

A complete randomized block design with three replicates and 30 cuttings sample in each replicate for mulch applications, for both grape rootstcks were established. The numerical data obtained were compared with Student's t-test at 0.05 significance level using SPSS 17.0 and JMP 7 statistical programs.

\section{Results and Discussion}

\section{Stomatal conductivity (mmol $\left.\mathrm{m}^{-2} \mathrm{~s}^{-1}\right)$}

Mulch applications on stomatal conductivity were significant ( $\mathrm{p}<0.05$ ) (Figure 1). Generally, the values obtained from 110R were higher than Fercal, but when the measurement times and applications were evaluated together, there was no stable situation in both rootstocks. On 30 July, the highest stomatal conductivity was recorded as $261.86 \mathrm{mmol} \mathrm{m}^{-2} \mathrm{~s}^{-1}$ in Fercal control and $296.33 \mathrm{mmol} \mathrm{m}^{-2} \mathrm{~s}^{-1}$ in BD application in $110 \mathrm{R}$. On August 20, the highest values [(Fercal $316.80 \mathrm{mmol} \mathrm{m}^{-2}$ $\left.\mathrm{s}^{-1}, 110 \mathrm{R} 331.73 \mathrm{mmol} \mathrm{m} \mathrm{m}^{-2} \mathrm{~s}^{-1}\right)$ ] were detected in BP application, on August 10, the maximum values were detected in Fercal control as $313.30 \mathrm{mmol} \mathrm{m}^{-2} \mathrm{~s}^{-1}$ and in 110R PJ application as $347.27 \mathrm{mmol} \mathrm{m}^{-2} \mathrm{~s}^{-1}$. On August 20 , the highest values were detected in [(Fercal 316.80 mmol m $\mathrm{m}^{-2}$, 110R $\left.331.73 \mathrm{mmol} \mathrm{m}^{-2} \mathrm{~s}^{-1}\right)$ ] BP aplication. On September 10, the highest values were $31.30 \mathrm{mmol}$ $\mathrm{m}^{-2} \mathrm{~s}^{-1}$ in Fercal control and $347.27 \mathrm{mmol} \mathrm{m}^{-2} \mathrm{~s}^{-1}$ in $110 \mathrm{R}$ PJ aplication. On September 1, the maximum values were determined in BD application in Fercal (265.53 mmol m $\left.\mathrm{m}^{-2} \mathrm{~s}^{-1}\right)$ and PJ applications in 110R (368.63 mmol m $\mathrm{m}^{-2}$ ). In a similar study, Zengin (2019), $99 \mathrm{R}$, 44-53 M, Rupestris du Lot and 41B grape rootstock seedlings did not show a stable situation in the effect of mulch applications on stomatal conductivity.

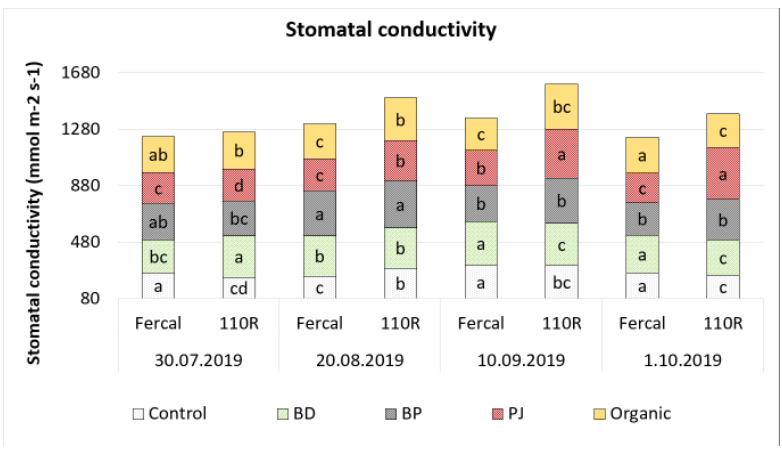

Figure 1

Effects of mulch applications on stomatal conductivity $\left(\mathrm{mmol} \mathrm{m} \mathrm{s}^{-1}\right)$.

\section{Leaf temperature $\left({ }^{\circ} \mathrm{C}\right)$}

The effects of mulch applications on leaf temperature (Figure 2) were also important in 4 measurement periods ( $p$ <0.05). While the BP application in the Fercal rootstock gave the highest leaf temperature as a value of $31.02{ }^{\circ} \mathrm{C}$ on July 30 , the PJ application gave the highest value in $110 \mathrm{R}$ rootstock as $32.06^{\circ} \mathrm{C}$. On 20 August, OM application on both rootstocks [(Fercal $29.40{ }^{\circ} \mathrm{C}$ and $\left.110 \mathrm{R} 29.60{ }^{\circ} \mathrm{C}\right)$ ] gave the highest leaf temperature values. On September 10, BP applied samples were on both rootstocks [(Fercal $31.57^{\circ} \mathrm{C}$ and $\left.110 \mathrm{R} 31.33^{\circ} \mathrm{C}\right)$ ] had the highest temperature value. In the determinations dated 1 October, the application of $\mathrm{OM}$ in both rootstocks [(Fercal $30.23{ }^{\circ} \mathrm{C}$ and $110 \mathrm{R}$ $\left.30.23{ }^{\circ} \mathrm{C}\right)$ ] gave the highest leaf temperature. According to the data obtained, it increased the leaf temperature of BP, OM and PJ applications, respectively. In a previous study, Doğan (2020) reported that the effects of different mulch applications were significant in the 
grape variety of Trakya İlkeren, and were listed as Control $\left(33.46{ }^{\circ} \mathrm{C}\right)$, Straw $\left(32.80{ }^{\circ} \mathrm{C}\right)$, BP $\left(32.79{ }^{\circ} \mathrm{C}\right)$ and Pumice $\left(32.61{ }^{\circ} \mathrm{C}\right)$ mulches.

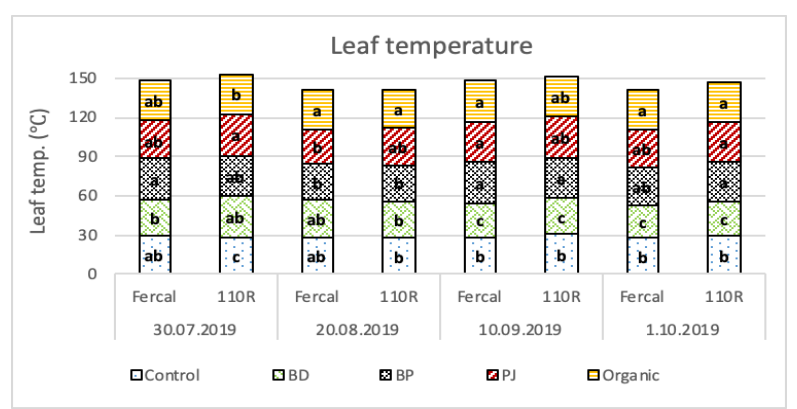

Figure 2

Effects of mulch applications on leaf temperature $\left({ }^{\circ} \mathrm{C}\right)$

Leaf chlorophyll content (spad value, $\mathrm{mg} \mathrm{kg}^{-1}$ )

The effects of mulch applications on leaf chlorophyll content (Figure 3) were also significant in 4 measurement periods ( $\mathrm{p}<0.05)$, BP and PJ increased leaf chlorophyll content more than the other applications. In the measurements performed on 30 July and 20 August, PJ application gave the highest Spad values in the Fercal rootstock as $23.42 \mathrm{mg} \mathrm{kg}^{-1}$ ve $26.48 \mathrm{mg} \mathrm{kg}^{-1}$ and in 110 R rootstock BP application has the highest value as $7.29 \mathrm{mg} \mathrm{kg}^{-1}$ and $27.50 \mathrm{mg} \mathrm{kg}^{-1}$ respectively. On September 10, BP mulch had the highest leaf chlorophyll value in both rootstocks [(Fercal $26.91 \mathrm{mg} \mathrm{kg-1}$ and 110R $25.27 \mathrm{mg} \mathrm{kg}^{-1}$ )]. On October 1, PJ application in Fercal rootstock gave the highest SPAD value as $27.92 \mathrm{mg} \mathrm{kg}^{-1}$, while OM gave the highest leaf chlorophyll value as $26.43 \mathrm{mg} \mathrm{kg}^{-1}$ in $110 \mathrm{R}$.

In a similar study, Doğan (2020), reported that in the combination of Trakya İlkeren / 1103P, in 50\% irrigation and BP mulch has the highest leaf chlorophyll content as $38.8 \mathrm{mg} \mathrm{kg} \mathrm{mg}^{-1}$ compared to other mulch applications. Zengin (2019), reported that synthetic mulch applications significantly increased leaf chlorophyll content in their study with different rootstocks of 99R, 44-53M, Rupestris du Lot and 41B. Curtis (2013), reported that leaf chlorophyll content was greater than control as $39.9 \mathrm{mg} \mathrm{mg} \mathrm{kg}^{-1}$ in those who applied OM in the Vitis vinifera vineyard, and increased vine growth and productivity.

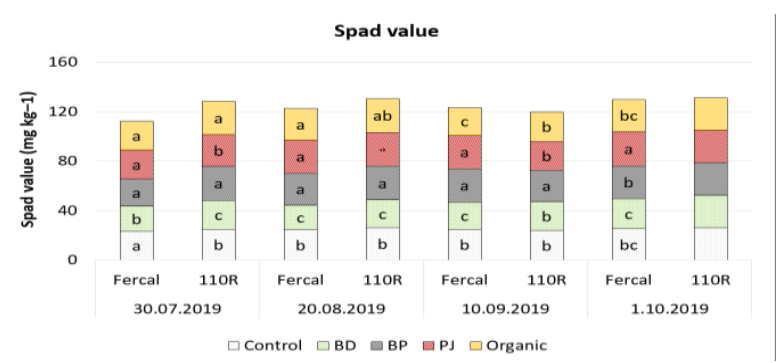

Figure 3

Effects of mulch applications on leaf clorophil content

Soil temperature $\left({ }^{\circ} \mathrm{C}\right)$
The effects of mulch applications on soil temperature (Figure 4$)$ were significant $(\mathrm{p}<0.05)$. According to the applications in both rootstocks, a stable condition was not observed in soil temperature values. The soil was the hottest in both rootstocks (Fercal $23.17^{\circ} \mathrm{C}$ and 110R $23.00^{\circ} \mathrm{C}$ ) on which BP was applied at July 30. On August 20, PJ application in Fercal rootstock gave the highest soil temperature as $23.17{ }^{\circ} \mathrm{C}$, and $110 \mathrm{R}$ rootstock as $22.80{ }^{\circ} \mathrm{C}$. On September 10, in 110R rootstock, the highest soil temperature was determined in $\mathrm{OM}$ application as $21.83{ }^{\circ} \mathrm{C}$, while the effects of applications on soil temperature in Fercal rootstock were statistically insignificant. In the last determinations made on 1 October, Fercal control gave the highest soil temperature value, while the effects of the applications on soil temperature were insignificant in 110R.

In one of the previous studies, Dağ (2017), achieved the highest soil temperature in BP application the Michele Palieri / $41 \mathrm{~B}$ combination as $25.3^{\circ} \mathrm{C}$ and indicated that this value was $3.7^{\circ} \mathrm{C}$ higher than the control. Abramova (1984), reported that the application of synthetic mulch in the production of Areni and Burmunk grape vine saplings increased the soil temperature by $1.5-3{ }^{\circ} \mathrm{C}$. Küçükyumuk (2009), stated that in the production of Alphonse Lavallée grapevine grafted onto $140 \mathrm{Ru}, 5 \mathrm{BB}, 41 \mathrm{~B}$ rootstocks, soil temperatures are listed as BP, Rose pulp, Control and Grass residue mulch applications from high to low. Zenginoğlu (2015), stated that in the combination of Sultani Çekirdeksiz / 1613, in the production of vine saplings, different mulch applications were compared and the soil temperature was higher in BP and upper surface gray bottom surface black mulch applications, and mulch applications had an effect on increasing soil temperature.

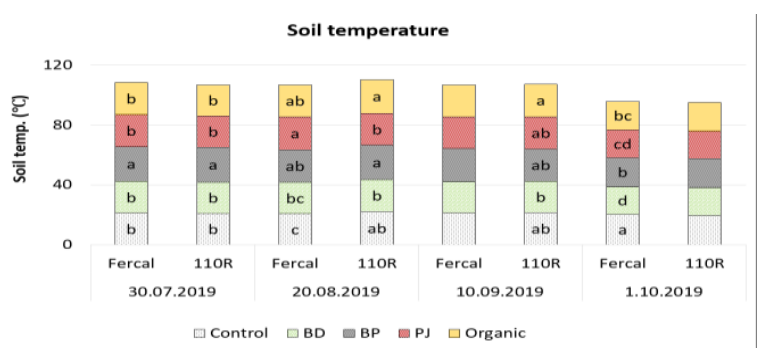

Figure 4

Effects of mulch applications on soil temperature $\left({ }^{\circ} \mathrm{C}\right)$,

Leaf area ( $\mathrm{cm} 2)$

The effects of mulch applications on leaf area $(\mathrm{Fi}-$ gure 5) were significant $(\mathrm{p}<0.05)$ and differed by rootstocks. In Fercal grape vine rootstock, all applications were above the control and the highest value as $143.50 \mathrm{~cm} 2$ was in the BP application, while in $110 \mathrm{R}$ rootstock the highest value as $66.75 \mathrm{~cm} 2$ was recorded in OM application. In a similar study previously conducted, Zengin (2019) reported that in the 41B rootstock, BP and OM applications increased leaf temperature up to $51 \%$ and $48 \%$, respectively. 


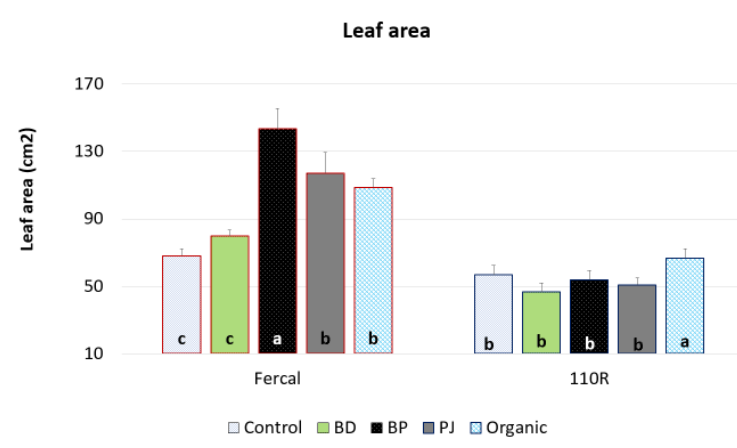

Figure 5

Effects of mulch applications on leaf area $\left(\mathrm{mg} \mathrm{kg}^{-1}\right)$.

\section{Number of leaves and roots (pieces)}

The effects of mulch applications on the number of leaves (Figure 6) were significant $(\mathrm{p}<0.05)$ and differed by rootstocks. OM application gave the highest number of leaves in both rootstocks (Fercal as 30.13 pieces and $110 \mathrm{R}$ as 29.05 pieces. All mulch applications in Fercal rootstock, BP and OM applications in $110 \mathrm{R}$ rootstock increased the number of leaves. While the highest number of roots was determined as 28.83 in BP application in Fercal, it was determined as 15.28 in OM application in 110R rootstock. In similar studies, In a similar study, Zengin (2019) reported that the application of OM on $99 \mathrm{R}, 44-53 \mathrm{M}$, Rupestris du Lot and $41 \mathrm{~B}$ grape rootstocks increased the number of leaves up to $30 \%$. Dağ (2017), Zenginoğlu (2015), Küçükyumuk (2009) obtained the highest number of roots from BP application.

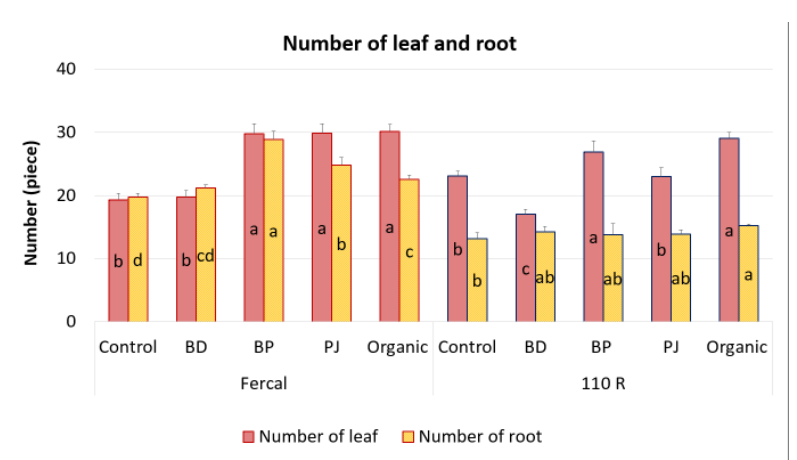

Figure 6

Effects of mulch applications on number of leaf and root (pieces).

\section{Leaf weight $(g)$}

The effects of mulch applications on leaf weights (Figure 7) were significant ( $p<0.05)$. In Fercal, BP (3.30 $\mathrm{g}$ fresh $1.14 \mathrm{~g}$ dry) mulch gave the highest fresh leaf weight, whereas fresh and dry leaf weights were above the control in all applications. While the highest fresh leaf weight value was determined in OM $(1.50 \mathrm{~g})$ application in $110 \mathrm{R}$, the difference between dried samples was insignificant ( $\mathrm{p}<0.05)$. In similar studies by Zengin (2019), and Ross (2010), mulch applications have been reported to increase fresh leaf weight. Zengin (2019), reported that the application of leaf dry weight BP (0.93 g) increased in the Rupestris du Lot rootstock.

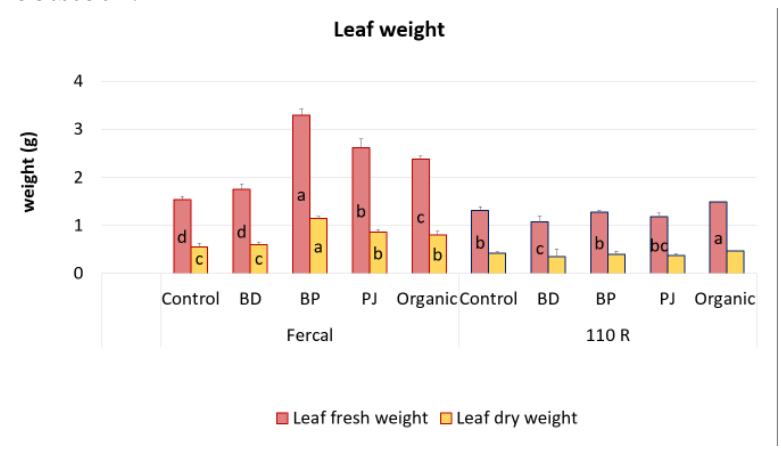

Figure 7

Effects of mulch applications on leaf weight $(\mathrm{g})$.

Shoot length $(\mathrm{cm})$

The effects of mulch applications on total and lignified shoot length (Figure 8 ) were significant $(p<0.05)$ and the values were more than $110 \mathrm{R}$ in Fercal. In Fercal rootstock, the highest total as $130.73 \mathrm{~cm}$ and woody as 121.87 shoot length was recorded in BP application, followed by PJ and OM applications. In this rootstock, the shoot length values obtained from the BD application remained under control. In 110R, OM application came to the fore with the total as $94.76 \mathrm{~cm}$ and woody as $86.31 \mathrm{~cm}$ shoot length value. In previous studies where BP application increased the length of shoots, it was reported by Zengin (2019), Dağ (2017), Zenginoğlu (2015), Küçükyumuk (2009), Van der Westhuizen (1980).

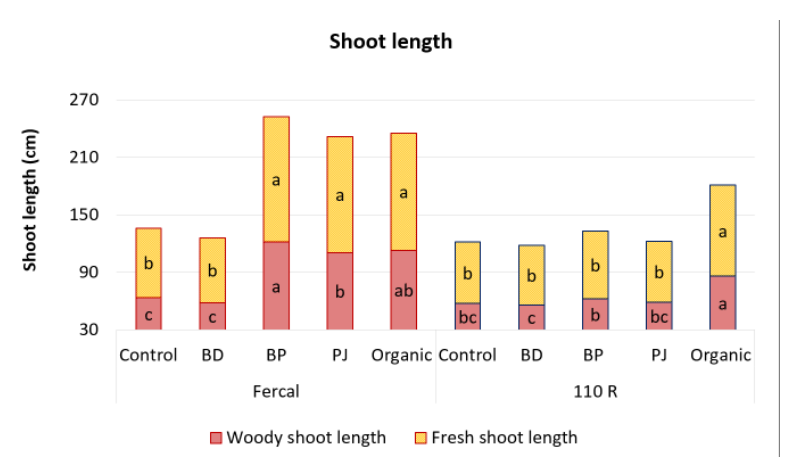

Figure 8

Effects of mulch applications on shoot length $(\mathrm{cm})$

\section{Shoot and root diameter $(\mathrm{mm})$}

The effects of mulch applications on shoot and root diameter (Figure 9) were significant $(\mathrm{p}<0.05)$, differed by rootstocks (Figure 2), and in the same trend with shoot length, and the values were more than 110R in Fercal. The highest shoot length in BP application as $5.97 \mathrm{~mm}$ in Fercal and OM application as $4.89 \mathrm{~mm}$ in $110 \mathrm{R}$ gave the highest values. OM application [(Fercal $2.65 \mathrm{~mm}$ and $110 \mathrm{R} 2.80 \mathrm{~mm}$ )] gave the highest root diameter in both rootstocks, followed by PJ and BP applications with close values. In similar studies, where in BP application increased the diameter of the shoot, it was reported by Zengin (2019), Dağ (2017), Küçükyumuk (2009). 


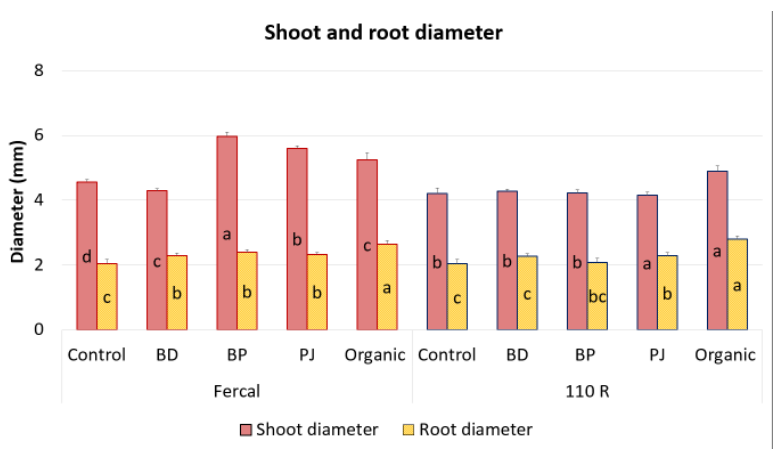

Figure 9

Effects of mulch applications on shoot and root diameter (mm).

\section{Pruning residue weight ( $g$ )}

The effects of mulch applications on pruning residue weight were significant $(\mathrm{p}<0.05)$ and different from rootstocks (Figure 10) and the values were more than 110R in Fercal. The OM application gave the highest pruning residue weight as $31.88 \mathrm{~g}$ in Fercal rootstock and $17.54 \mathrm{~g}$ in $110 \mathrm{R}$ rootstock. Similar effects of BP application were reported by Dă̆ (2017) and Küçükyumuk (2009).

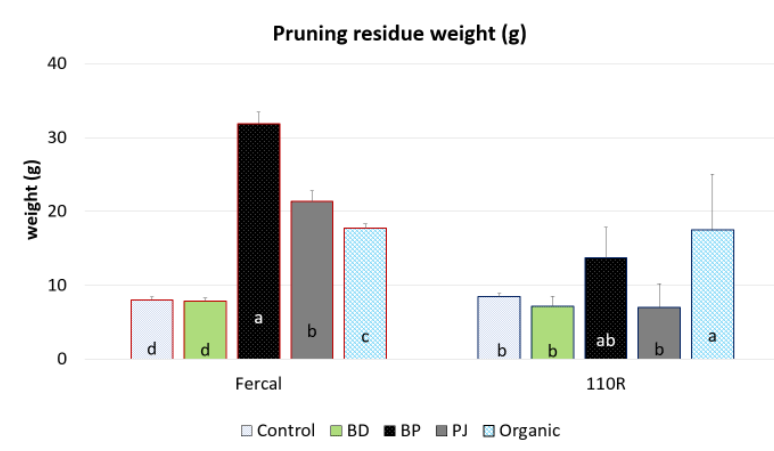

Figure 10

Effects of mulch applications on Pruning residue weight $(\mathrm{g})$.

Shoot and root development level (0-4 scale)

BP, PJ, and OM applications significantly increased the shoot growth $(\mathrm{p}<0.05)$ (Figure 11) in Fercal and the only $\mathrm{OM}$ in $110 \mathrm{R}$, and all mulche inreased root developemnt in both rootstocks. In Fercal, BP (3.09) and PJ (3.03) gave higher values than the control and BD applications. The highest shoot development in 110R was obtained by the OM (2.49) application. Root growth level in Fercal gave the highest root scale in PJ (3.83) application, while $\mathrm{BD}$ (3.06) application in 110R.

In previous studies, Zenginoğlu (2015) reported that Sultani Çekirdeksiz / 1613 saplings were the highest shoot development level in BP (2.9) application. Küçükyumuk (2009) reported that BP application significantly increased the level of shoot growth compared to other mulch applications in the production of Alphonse Lavallée grapevine grafted onto $140 \mathrm{Ru}, 5 \mathrm{BB}$, 41B. Dağ (2017), Michele Palieri / 41B had the highest shoot growth level in sapling production as 2.10 scale from BP application. In similar studies conducted by Dağ (2017), Zenginoğlu (2015), Küçükyumuk (2009) it was reported that BP applications significantly increased the level of root development.

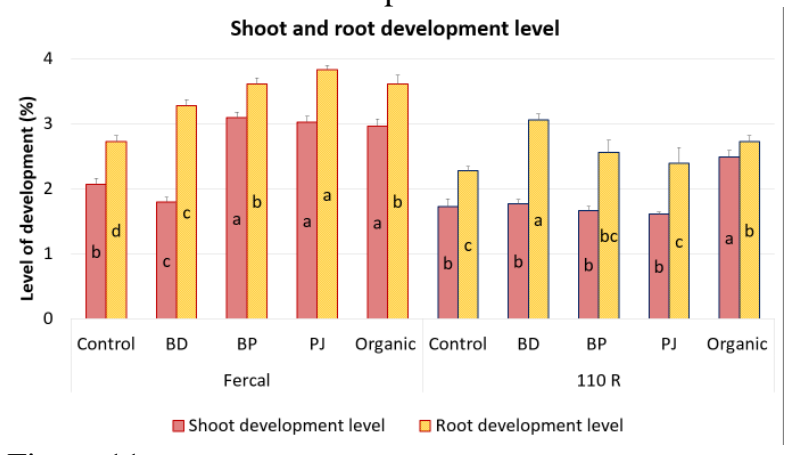

Figure 11

Effects of mulch applications on shoot and root development level (0-4 scale).

Root fresh and dry weight $(g)$

All of the mulch applications significantly increased the root fresh and dry weight $(\mathrm{p}<0.05)$ (Figure 12) and the values were more than $110 \mathrm{R}$ in Fercal. In Fercal, BP (25.78 g) and OM (24.90 g) applications significantly increased the root fresh and dry $(12.00 \mathrm{~g}$ and $11.97 \mathrm{~g}$ ) weight. The highest root in Fercal rootstock was obtained from BP application with its fresh weight. The highest root fresh (7.05 g) and dry weight $(3.54 \mathrm{~g})$ were determined in OM application at 110R rootstock. In similar studies, Dağ (2017), Küçükyumuk (2009) reported that the application of BP increases the root age weight of $41 \mathrm{~B}$ grapevine seedling production. Van der Westhuizen (1980) reported that vines with plastic mulch have higher root weight due to higher soil moisture. Van Huyssteen and Weber (1980) obtained higher hanging root density from OM than other mulch applications.

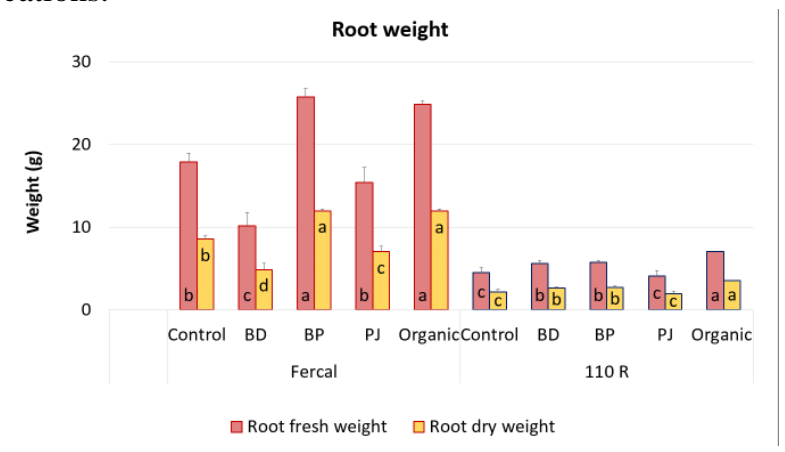

Figure 12

Effects of mulch applications on root weight (g).

Sapling efficiency (\%)

BP and OM applications increased the 1st and 2nd grade seedlings efficiency ( $\mathrm{p}<0.05$ ) (Figure 13) and the values were more than $110 \mathrm{R}$ in Fercal. The highest 1 st $(28.33 \%)$ and 2 nd grade $(44.17 \%)$ seedlings yield in Fercal were obtained by BP application, and in $110 \mathrm{R}$, it was obtained by $\mathrm{BD}$ and $\mathrm{OM}$ application (49.17\%, 20.00\%, respectively). In similar studies, Da (2017), Küçükyumuk (2009), Zenginoğlu (2015) BP application significantly increased the yield of 1 st and 2nd grade seedlings in vine sapling production, Zengi- 
noğlu (2015), black mogul (17.5) mulch application in the production of open-rooted vine seedlings. He reported that he gave a high 2 nd grade sapling yield value. Akman (2009), reported that in the production of seedlings in the combination of Tekirdağ Çekirdeksizi / $5 \mathrm{BB}$, the second-grade seedlings yield was 14.84 in control, while the efficiency in mulch applications remained lower with 12.25 .

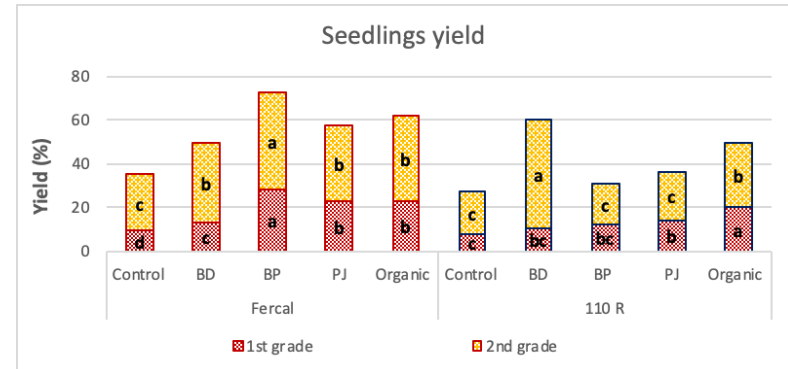

Figure 13

Effects of mulch applications on sapling yield (\%).

\section{Conclusion}

Mulch practices had significant effects on all the characters examined and the overall efficacy rank varied according to the character and rootstocks. Vegetative development was more than $110 \mathrm{R}$ in Fercal. Stomatal conductance values were higher in $110 \mathrm{R}$ than Fercal, but when measurement times and applications were evaluated together, there was no stable situation in both rootstocks. While the leaf temperature increasing effect, order was determined as SP, OM and PJ, and the efficiency of increasing leaf chlorophyll content was listed as SP, PJ and OM. No stable variance was observed in soil temperature values, the activity from high to low was listed as BP and PJ and OM, BD.

In the Fercal grapevine rootstock, the leaf area was above the control in all applications and the efficacy order was determined as BP, PJ, OM, BD and Control, while the single value above the control in $110 \mathrm{R}$ was determined in the OM application.

While OM, BP and PJ applications increased the number of leaves in both rootstocks, others were in the same group with control.

The order of activity in increasing leaf weight was $\mathrm{BP}, \mathrm{PJ}, \mathrm{OM}, \mathrm{BD}$ in Fercal. In the 110R rootstock, the effect of $\mathrm{BD}$ and $\mathrm{PJ}$ remained limited, while $\mathrm{OM}$ and BP increased leaf weights.

The effects of mulch applications on total and woody shoot length were listed as in Fercal, BP, OM and $\mathrm{PJ}$, while $\mathrm{BD}$ and $\mathrm{BD}$ were in the same group with control. In the $110 \mathrm{R}$ rootstock, OM application increased the total and lignified shoot length, while the others were in the same group with control.

While the pruning residue weight increased in Fercal BP and PJ, OM applications significantly, BD was in the same group with the control. In the $110 \mathrm{R}$ rootstock, $\mathrm{OM}$ and $\mathrm{BP}$ applications increased the pruning residue weight, while $\mathrm{PJ}, \mathrm{BD}$ and control were in the same group.
All the applications of mulch increased the level of shoot and root development. While the activity was ranked as BP, PJ and OM in Fercal, BD remained under control. In the rootstock $110 \mathrm{R}$, only OM significantly increased the level of growth, while other applications were in the same group with control. While all applications increased in root development levels, the ranking was $\mathrm{BD}, \mathrm{OM}, \mathrm{BP}, \mathrm{PJ}$ and Control.

BP, PJ, OM and BD applications in Fercalde, and $\mathrm{OM}$ and $\mathrm{PJ}$ applications in 110R increased the diameter of shoots. In Fercal root diameter was affected by the applications in the same way as shoots and the activity was listed as BP, PJ, OM and BD. In 110R, OM, PJ and $\mathrm{BP}$ applications increased the root diameter.

When the root fresh and dry weight were evaluated together, in Fercal BP and OM, and in 110R, OM, BP and $\mathrm{BD}$ came to the fore.

The efficiency of the applications for total seedling efficiency and 1st and 2nd grade seedlings efficiency were listed in Fercal in the same way (BP, OM, PJ and $\mathrm{BD})$ and $\mathrm{BB}, \mathrm{OM}, \mathrm{PJ}$ and $\mathrm{BP}$ in $110 \mathrm{R}$.

Since, significant differences were found at the level of the examined characteristics in both rootstocks, it may be recommended to select mulches according to the effect expected from mulch applications in the future studies.

\section{Acknowledgements}

The authors are grateful to Selcuk University Research Funds (Project No: 20201020 as the master thesis of M.S.M. Fakhar) for supporting this study. Conflict of interest

Z. Kara, M.S.M. Fakhar, declare that they have no competing interests.

\section{References}

Abramova L (1984) The use of black polyethylene in raising grape vine transplants. Horticultural Abstracts 54 (7):4374

Akman B (2009) Tekirdağ şartlarında Tekirdağ çekirdeksizi üzüm çeşidi fidanlık parsellerinde damla sulama yöntemiyle farklı sulama uygulamalarının fidan randımanı ve kalitesi üzerine etkileri. Yüksek Lisans Tezi, Namık Kemal Üniversitesi Fen Bilimleri Enstitüsü $50 \mathrm{~s}$

Arslan ZF, Uygur FN (2014) Sebze üretiminde sorun olan yabancı otlara karşı bazı yeni ve etkili yöntemler: malç tekstili, firçalama aleti ve keser çapa. Bitki Koruma Bülteni 54 (3):219-232

Bakshi P, Wali VK, Iqbal M, Jasrotia A, Kour K, Ahmed R, Bakshi M (2015) Sustainable fruit production by soil moisture conservation with different mulches: A review. AJAR 10 (52):4718-4729

Chan K, Fahey D, Newell M, Barchia I (2010) Using composted mulch in vineyards-effects on grape yield and quality. IJFS 10 (4):441-453

Cowan JS (2013) The use of biodegradable mulch for tomato and broccoli production: crop yield and quality, mulch deterioration, and growers'perceptions. Ph.Doctor, Washington State Unıversity, 198p 
Curtis MA (2013) Influence of cover crop residue management on soil moisture, vine growth, and productivity in a pre-production vineyard in the Willamette Valley. Masters Thesis, Oregon State University, 95p

Dağ S (2017) Michele palieri \41B aşılı asma fidanı üretiminde farklı alıştırma süreleri ve siyah plastik malç uygulamasının fidan randımanı ve kalitesi üzerine etkileri. Yüksek Lisans Tezi, Süleyman Demirel Üniversitesi Fen Bilimleri Enstitüsü 53s

Doğan G (2020) Trakya ilkeren üzüm çeşidinde sulama ve malç Uygulamalarının verim, kalite ve Ekofizyolojik özelliklere etkisi. Yüksek Lisans Tezi, Çukurova Üniversitesi Fen Bilimleri Enstitüsü 77s

Faostat (2020) Access date. http://wwwfaoorg/faostat/en/\#data/QC: 30.06 .2020

Ferrara G, Fracchiolla M, Al Chami Z, Camposeo S, Lasorella C, Pacifico A, Aly A, Montemurro P (2012) Effects of mulching materials on soil and performance of cv. Nero di Troia grapevines in the Puglia region, southeastern Italy. AJEV 63 (2):269-276

Hostetler GL, Merwin IA, Brown MG, Padilla-Zakour O (2007) Influence of geotextile mulches on canopy microclimate, yield, and fruit composition of Cabernet franc. AJEV 58 (4):431-442

Ingels C (1992) Sustainable agriculture and grape production. AJEV 43 (3):296-298

Kanber R, Tekinel O, Baytorun N, Kumova Y, Alagöz T (1991) Harran Ovası Koşullarında pamuk sulama aralığ1 ve su tüketiminin belirlenmesinde açık su yüzeyi buharlaşmasından yararlanma olanakları. . TC Başbakanlık GAP Kalkınma İdaresi Başkanlığı GAP Yayın (44):15-25

Kara Z, Sabır A, Yazar K, Akçay A (2017) Klinoptilolitik mikronize zeolit uygulamalarının asma anacı fidanlarının vegetatif gelişme ve kalitesine etkileri. Selçuk Tarım Bilimleri Dergisi 3 (2):253-260

Król-Dyrek K, Siwek P (2015) The influence of biodegradable mulches on the yielding of autumn raspberry (Rubus idaeus L.). Folia Horticulturae 27 (1): $15-20$

Küçükyumuk C (2009) Aşılı asma fidanı üretiminde farklı sulama aralıkları ve malç uygulamalarının fidan randımanı ve kalitesi üzerine etkileri. Doktora Tezi, Süleyman Demirel Üniversitesi, Fen Bilimleri Enstitüsü $188 \mathrm{~s}$

Mundy D, Agnew R (2002) Effects of mulching with vineyard and winery waste on soil fungi and botrytis bunch rot in Marlborough vineyards. N Z Plant Prot 55:135-138

Nauleau F (1997) Nouvelles techniques d'entretien des sols viticoles. Conséquences oenologiques Synthése de 5:188190

Nazrala JJB (2008) Influencia del manejo del suelo y las coberturas vegetales en el microclima de la canopia de la vid, la composición de la uva y el vino. Rev Fac Cienc Agrar 40 (1):85-104

Ross OC (2010) Reflective mulch effects on the grapevine environment, Pinot noir vine performance, and juice and wine characteristics. Master of Applied Science, Lincoln University, 89p

Van der Westhuizen J (1980) The effect of black plastic mulch on growth, production and root development of chenin blanc vines under dryland conditions. SAJEV 1 (1): $1-6$

Van Huyssteen L, Weber H (1980) The effect of selected minimum and conventional tillage practices in vineyard cultivation on vine performance. SAJEV 1 (2):77-83

Watson (2006) Mulch softens the big dry. Australian Viticulture 10, 74 - 75

Wheeler SJ, Black A, Pickering G (2005) Vineyard floor management improves wine quality in highly vigorous Vitis vinifera'Cabernet Sauvignon'in New Zealand. New Zeal J Crop Hort:317-328

Zengin H (2019) Farklı malç uygulamalarının bazı asma anaçlarının gelişimi üzerine etkileri. Yüksek Lisans Tezi, Selçuk Üniversitesi, Fen Bilimleri Enüstitüsü 43s

Zenginoğlu M (2015) Açık köklü asma fidanı üretiminde farklı malç materyalleri ve gölgeleme oranlarının fidan randıman ve kalitesine etkileri. Yüksek Lisans Tezi, Gaziosmanpaşa Üniversitesi, Fen Bilimleri Enstitüsü 55s

Zhang Q, Wang S, Li L, Inoue M, Xiang J, Qiu G, Jin W (2014) Effects of mulching and sub-surface irrigation on vine growth, berry sugar content and water use of grapevines. AWM 143:1-8 